
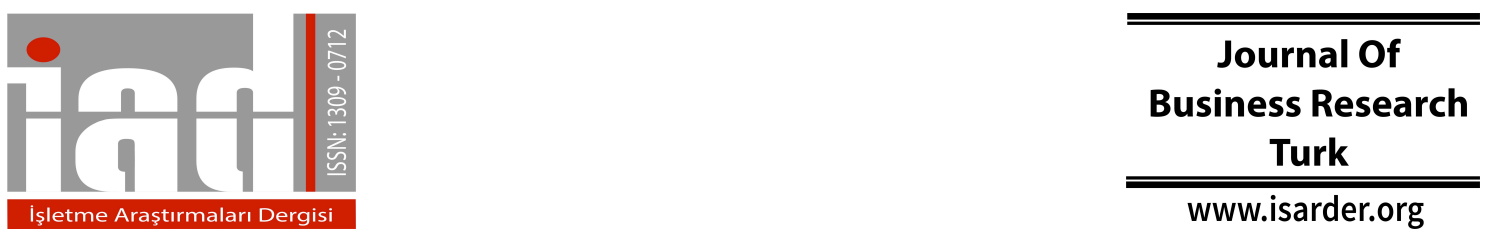

www.isarder.org

\title{
İşletmelerin Sahip Oldukları Bilgi ve İletişim Teknolojileri Kabiliyetinin Çalışanların Yenilikçi Davranışlarına Etkisi: Lider Desteğinin Aracılık Rolü \\ Influence Of Organization's Knowledge And Communication Skills On Employee's Innovation Behavior: Mediating Role Of Leader Support
}

\author{
Nazmiye Ülkü PEKKAN \\ Osmaniye Korkut Ata \\ Üniversitesi \\ Osmaniye, Türkiye \\ orcid.org/0000-0001-7298-0552 \\ nazmiyeulku.pekkan@gmail.com
}

\author{
Abdullah ÇALIŞKAN \\ Toros Üniversitesi \\ Mersin SBYO, Sağlık Yönetimi Bölümü \\ Mersin, Türkiye \\ orcid.org/0000-0001-5746-8550 \\ abdullah.caliskan@toros.edu.tr
}

\section{Özet}

$\mathrm{Bu}$ çalışmanın amacı, işletmelerin sahip oldukları bilgi ve iletişim teknolojileri kabiliyetlerinin (BİTK) dört alt boyutunun, çalışanların yenilikçi davranışlarına etkisi ve bu etkide lider desteğinin aracılık rolünün tespit edilmesidir. Söz konusu değişkenler arasındaki ilişki; faktör analizi, regresyon analizi ve sobel testleri gibi istatistiksel yöntemler kullanılarak analiz edilmiştir. Çalışmada Ankara'da elektronik haberleşme sektöründe faaliyet gösteren işletme çalışanları ele alınmıştır. Bu doğrultuda hazırlanan anket formu ile 568 çalışandan toplanan veriler kullanılarak çalışmada yer alan değişkenler arasındaki ilişkiler belirlenmeye çalışılmıştır. Çalışma sonucunda, bilgi ve iletişim teknolojileri kabiliyetinin tüm alt boyutlarının (bilgi teknolojileri eğitimi, bilgi teknolojileri stratejisi, haberleşme ve güncel takip uygulamaları ve iş zekası uygulamaları) yenilikçi davranışı pozitif yönde etkilediği ve lider desteğinin bilgi ve iletişim teknolojileri kabiliyetleri ile yenilikçi davranış ilişsisinde kısmi aracılık rolünün olduğu belirlenmiştir.

Anahtar Kelimeler: Bilgi ve İletişim Teknolojileri, Yenilikçi Davranış, Lider Desteği, Aracilık Etkisi.

\section{Abstract}

The aim of this study is to identify the impact of four sub-dimensions of information and communication technologies capabilities (the information technology education, information technology strategy, communication and current follow-up applications, business intelligence applications) on the innovative behaviors of employees and to determine the mediating role of leader support on this impact. The relationship between these variables was analyzed by statistical methods such as correlation and regression analysis, and hierarchical regression analysis was used in testing the mediation effect. Sobel tests were then conducted to confirm the mediation tests. In this study, employees of enterprises operating in electronic communication sector in Ankara were dealt. It was tried to determine the relations between the variables 
with the data gathered from 568 employees by using the questionnaire prepared in this study. As a result of the study, it was determined that the four dimensions of information and communication technologies capabilities are affecting innovative behaviors positively and influential leader support has a partial intermediary role in the relationship between information and communication technologies capabilities and innovative behavior.

Keywords: Information and Communication Technologies, Innovative Behavior, Leader Support, Mediating Effect.

\section{Giriş}

Günümüz rekabet koşulları göz önünde bulundurulduğunda işletmelerin bu zorlu koşullar altında hayatta kalabilmeleri ve rakipleri arasından sıyrilarak fark yaratabilmeleri çeşitli yöntemler ve stratejiler geliştirmeleri ile mümkün olmaktadır (Som, 2008). Bu değişim ve gelişimler özellikle bilgi teknolojileri alanında gerçekleşmektedir. Geçmişte yalnızca bilgi teknoloji aracı olarak kullanılan pek çok sistem benzer altyapı üzerinde kurulan verilerin birbirine aktarım imkânı sağlaması sebebiyle bir araya gelerek bilgi ve iletişim teknolojilerini ortaya çıkarmıştır. Geçmişte yalnızca bilgi teknolojisi olarak kullanılan pek çok araç artık iletişim teknolojisi olarak da kullanılmaya başlamıştır. Bu durumun belki de en çarpıcı örneği internetin bilgi teknoloji aracı olarak ortaya çıkması ve artık bir iletişim aracı olarak da kullanıyor olmasıdır (Vijayanand ve Ananda, 2003 akt. Börekçi, 2007). Bu denli hızlı bir gelişimin işletmelere yansıması da bilgi ve iletişim teknolojilerini işletme süreçlerine aktarabilme ve bunu etkili bir şekilde kullanabilme becerilerine yansımıştır. İşletmelerin sürekli bir değişimin yaşandığı bu alanlardaki gelişmelere ve yeniliklere uyum sağlayabilmeleri etkinlik ve verimliliklerinde dolayısıyla işletme performanslarında etkili olacaktır. İşletmeler için en önemli faktörlerden biri olan insan kaynağının söz konusu yeniliklere adapte edilmeleri ve yaratıcılıklarının desteklenmesi işletme amaçlarının gerçekleştirilmesinde kilit rol oynamaktadır.

Bilgi iletişim teknolojileri, bir yerden başka bir yere, bir kişiden başka bir kişiye ya da bir makineden başka bir makineye bir ortam aracılığı ile bilgi aktarma amacı taşıyan tüm teknolojik olanaklar olarak tanımlanmaktadır (Köksal, 1981). Bir başka tanıma göre bilgi iletişim teknolojileri, çeşitli araçlar aracılığı ile bilgiye ulaşma, bilgiyi oluşturma ve bu bilginin başkaları ila paylaşımını sağlayan görsel, işitsel, yazılı veya basılı her türlü araç olarak tanımlanmaktadır (Çavaş vd., 2004 akt. Demirhan, 2012). Söz konusu bu araçların varlığı kadar işletme içerisinde bu araçların nasıl kullanıldığı da önemlidir. İşte bu noktada işletmelerin sahip oldukları bilgi ve iletişim teknolojileri kabiliyetleri ön plana çıkmaktadır. Bilgiye sahip olmak tek başına yeterli değildir. Asıl önemli olan durum, sahip olunan bilginin kullanımıdır. Teknolojik değişim ve gelişimleri takip etmek durumunda olan işletmelerin, müşteri istek ve ihtiyaçlarına anında cevap verebilecek her türlü teknolojik imkâna sahip olması bu teknolojileri tüm işletme süreçlerinde başarılı bir biçimde uygulaması ve çalışanlarını da bu sürece dâhil etmesi ile mümkün olabilecektir. Çalışanların özellikle değişim süreçlerinde işletme ile ilgili davranış ve tutumlarında lider desteğinin önemli olduğu düşünülmektedir. Liderlerin, çalışanlara destek sağlaması işletme içerisinde çalışanların gösterdikleri davranış ve tutumlarda etkili olarak çalışanların işletme ile ilgili hissettikleri duygularda ve performanslarında olumlu etkiler yaratmaktadır (Akyıldız ve Turunç, 2013). 
Lider desteği, işletme içerisinde görev yapan çalışanlara değer verilmesi, onlarla ilgilenilmesi ve çalışanlara destek verilmesi olarak tanımlanmaktadır (Babin ve Boles, 1996). Bir başka tanıma göre ise lider desteği; yöneticilerin çalışanlarına karşı samimi ve anlayışı bir tutum sergileyerek çalışanlar ile aralarında olumlu ilişkiler geliştirmesidir (Bhanthumnavin, 2003; Öz, 2007). Liderler, çalışanlarını işletme içerisinde duygusal ve yönetsel olmak üzere iki farklı biçimde desteklemektedirler. Liderliğin yenilikçiliği etkileyen en önemli faktörlerden biri olduğu öne sürülmektedir (Osborne, 1998; Schin ve McClomb, 1998). Liderler, çalışanları yenilikçiliğe yönlendirerek ve yenilikçi uygulamalara yönetsel destek sağlayarak, işletme amaçları doğrultusunda çalışanın performansını geliştirmekte ve örgütün yenilikçi süreç çıktılarına pozitif yönde katkı sağlamaktadırlar (Hasenfeld, 1983; Kossek vd., 2011). İlgili yazında lider desteği ile yapılan pek çok çalışma göstermiştir ki; liderlerin çalışanlarına karşı geliştirmiş ve göstermiş oldukları ilgi, samimiyet ve destek hem bireysel hem de örgütsel açıdan pek çok olumlu sonuçlar doğurmaktadır (Fındıkl1, 2014).

Yenilikçi Davranış, örgüt içerisindeki çalışanların yenilikçi bilgi ve fikirlerinin desteklenmesi ile başlayan ve sonrasında örgüt yararına olacak şekilde bu fikirlerin düzenlenerek ortaya çıkan ya da çıkacak problemlerin çözümünde kullanılması ile ilgili olan bir süreç olarak tanımlanmaktadır (Turgut ve Beğenirbaş, 2013). Bir başka tanıma göre ise yenilikçi davranış, örgütte teknolojik gelişim ve değişimlerin takip edilmesi, bu gelişmelerin örgütün iş süreçlerine aktarılması, yeni ve farklı fikirlerin desteklenerek uygulamaya geçilmesine imkân sağlanmasıdır (Yuan ve Woodman, 2010). Yoğun rekabet koşulları altında farklılık yaratarak kalıcı olmak için çaba sarf eden işletmeler, yenilikçi ve yaratıcı fikirlerin örgüt içerisinde uygulanmasına destek sağlayarak bu davranış biçimlerinin yaygınlaşmasını sağlamalıdırlar (Mone vd., 1998). Bu düşünceler 1şığında, yenilikçi davranışların artırılması, işletmeler için bir problem sahası olarak görülmüş ve bu davranışın olumlu yönde geliştirilmesine etkisi olduğu düşünülen bazı değişkenlerin incelenmesinin gereği ortaya çıkmıştır. Bu kapsamda çalışmanın temel problem sahasi; elektronik haberleşme sektöründe faaliyet gösteren kurumların sahip oldukları bilgi ve iletişim teknoloji kabiliyetlerinin, çalışanların yenilikçi davranışları üzerindeki etkilerini belirlemek ve lider desteğinin bu iki değişken arasındaki etkide aracılık rolünü saptamak olarak belirlenmiştir.

\section{Teori ve Hipotezler}

İşletmelerin sahip olduğu bilgi ve iletişim teknolojileri kabiliyeti ve lider desteğinin çalışanların yenilikçi davranışlarına olan etkisi ve söz konusu bu etkide lider desteğinin aracılık rolünü tespit etmek üzere kurgulanan bu çalışmada ilk olarak literatür incelenerek teorik çerçeve ortaya konulmuştur. Bu kapsamda girdi değişken olarak ele alınan bilgi iletişim teknolojileri kabiliyeti ve lider desteği ile çıktı değişken olan çalışanların yenilikçi davranışı arasındaki ilişkiler araştırılmış ve ardından söz konusu bu ilişkilerin etkisinde lider desteğinin rolü ele alınarak hipotezler oluşturulmuştur.

\subsection{Bilgi ve İletişim Teknolojileri Kabiliyeti ve Yenilikçi Davranış}

Bilgi ve iletişim teknolojileri, bir işletmenin bilgi sistemlerine, süreçlerine yayılan ve birbirlerine bağlı uygulama ve verileri içeren geniş bir elektronik ağlardan oluşan bütün imkânları olarak tanımlanmaktadır (Kohli ve Melville, 2009). 
Yaşadığımız çağ bilgi ve teknoloji çağı olarak nitelendirildiğinden; bilgi ve iletişim teknolojilerinin de birçok alanda kullanıldığı yadsınamaz bir gerçek olarak karşımıza çıkmaktadır. Bilgi ve iletişim teknolojilerinde yaşanan hızlı gelişimler, işletmelerin teknolojik gelişmelerdeki yenilikleri takip etmelerini ve iş süreçlerinde bu teknolojilere yer vermeleri gerektiğini zorunlu hale getirmiştir. Söz konusu bu teknolojilerin işletmelerde yaygın bir biçimde kullanılması ve hatta işe alımlarda bu teknolojileri kullanma hâkimiyetine ve yeteneğine sahip olan kişilerin seçilmesi teknolojilerin etkinlik ve verimlilikte son derece önemli bir yer tuttuğunu gözler önüne sermektedir.

İşletmelerin çağın gerektirdiği değişim ve gelişimler doğrultusunda hedeflerine ulaşmasında bilgi ve iletişim teknolojilerinin öneminin anlaşılması, yenilikçilik ve yaratıcılıktan faydalanma ihtiyacını da doğurmaktadır. İşletmelerin sahip olduğu bilgi ve iletişim teknolojilerini kullanma kabiliyetlerinin işletmelerin en değerli varlıkları olan çalışanların yenilikçi davranışlarını etkileyen önemli bir unsur olarak düşünülmektedir.

Yenilik, rekabet avantajı sağlayan son derece güçlü bir kaynak olarak bilinmektedir (Sastry, 1999). Bu sebeple yenilik kavramı, yıllar boyunca çeşitli tanımlamaları içerecek şekilde anlam kazanarak pek çok farklı alanda (sektörel, bölgesel, işletme ve proje düzeylerinde) ve farklı biçimlerde ele alınıp incelenmiştir. Dolayısıyla yenilikçiliğin; işletmeler için son derece önemli olan verimlilik, etkinlik ve rekabet edebilirlikte kilit bir kavram olduğunu söylemek mümkündür (Osterloh ve Frey, 2000).

Yenilik, yeni ve fayda yaratan ürünlerin, prosedürlerin ve süreçlerin farkındalıkla uygulanması olarak ifade edilmektedir (West ve Farr, 1990).

Samuel (2000) yenilikçiliği, ister hizmet ister ürün üretimi olsun herhangi bir üretim için farklı üretim yöntemlerinin uygulanması ve organizasyonların iş süreçlerinde farklı yöntemlerin geliştirilmesi olarak tanımlamaktadır.

Thomson (1965) ise yenilikçiliği, bir organizasyonun iş süreçlerine, hizmetlerine ve ürünlerine yeni fikirlerin kabul edilmesi ve bu kabul edilen durumların organizasyon içerisinde başarılı bir şekilde uygulanması olarak ifade etmektedir. Diğer bir ifade ile yenilikçilik, işletme ürünlerinde yenilikler veya yeni fikirlerin miktarı, teknolojik yenilikler ve değişikliklere uyum olarak ifade etmektedir.

Yenilikçi davranış, organizasyon içerisinde görev yapan bir çalışanın farkında olarak ürünler, süreçler ve prosedürlere ait yeni fikirleri kendi iş rolüne, iş birimine veya organizasyonuna uygulaması veya benimsemesi olarak tanımlanmaktadır (West ve Farr, 1989). Organizasyonun en değerli kaynağı olan çalışanlar tarafından yapılan; yeni teknolojileri keşfetme, organizasyon amaçlarına ulaştıracak yeni ve farklı yollar önerme, yeni çalışma yöntemleri uygulama, ortaya çıkan yeni fikirleri uygulamak için var olan kaynakları güvence altına alma ve yeni kaynaklar araştırmaya devam etme gibi davranışlar yenilikçi davranış örnekleri olarak anılmaktadır (Yuan ve Woodman, 2010).

Bilgi ve iletişim teknolojileri ile yenilikçilik ve yenilikçi davranış arasındaki ilişkiyi inceleyen çalışmalarda (Mustafa, 2016; Işsklı, 2010), bilgi ve iletişim teknolojilerini kullanma düzeyinin yenilikçi davranışı etkilediği belirlenmiştir. 
Bilgi iletişim teknolojileri ile yenilikçi davranış arasındaki ilişkiyi irdeleyen çalışmalar ve kuramsal bilgilerden yola çıkarak bilgi iletişim teknolojileri kullanma kabiliyeti alt boyutlarının çalışanların yenilikçi davranışlarına etkisini belirlemek amacıyla kurgulanmış olan hipotezler aşağıda sunulmuştur.

Hipotez 1: Bilgi teknolojileri ĕ̆itimi, çalışanların yenilikçi davranışlarını pozitif ve anlamlı olarak etkiler.

Hipotez 2: Bilgi teknolojileri stratejisi, çalışanların yenilikçi davranışlarını pozitif ve anlaml olarak etkiler.

Hipotez 3: Haberleşme ve güncel takip uygulamaları, çalışanların yenilikçi davranışlarını pozitif ve anlamlı olarak etkiler.

Hipotez 4: İ̧̧ zekâsı uygulamaları, çalışanların yenilikçi davranışlarını pozitif ve anlamlı olarak etkiler.

\subsection{Bilgi ve İletişim Teknolojileri Kabiliyeti ve Lider Desteği}

İşletmelerin sahip oldukları bilgi ve iletişim teknolojileri kullanma kabiliyeti ile lider desteği değişkenlerini yerli ve yabancı literatürde bir arada inceleyen çalışma sayısının azlığı, lider desteğinin teknoloji kapsamında incelendiği çalışmalar üzerinden yorumlar yapmak durumunda birakmaktadır.

Yılmaz Börekçi (2009) liderlerin işletme içerisindeki faaliyetlerinde bilgi ve iletişim teknolojilerini kullanma düzeylerinin çalışanların iş ile ilgili tutumları üzerindeki etkilerini belirlemek üzere Türkiye'nin çeşitli illerinde farklı ilaç firmalarında çalışan 190 kişi üzerinde bir çalışma gerçekleştirmiştir. Çalışma sonucunda, liderler tarafından kullanılan bilgi ve iletişim teknolojilerinin çalışanların iş ile ilgili algılarını etkilediğini ve çalışanların sadakat, güven, iş tatmini ve adalet duyguları üzerinde pozitif ve anlamlı bir etkiye sahip olduğunu bulgulamıştır.

Gökoğlu ve Çakıroğlu (2014), okullarda görev yapmakta olan ve teknoloji lideri olarak görülen bilişim teknolojileri öğretmenlerinin teknolojik liderlik özelliklerini ortaya çıkarmak ve bu davranışları sergileyip sergilemediklerini tespit etmeye yönelik bir çalışma gerçekleştirmişlerdir. Çalışma sonucunda, çalıştıkları okullarda teknoloji liderliği yapan, teknolojik gelişmeleri takip eden ve bu gelişmeleri kurum içerisinde kullanan, bunun yanı sıra diğer tüm birimlerdeki bilgilerle teknoloji bilgisini birleştiren öğretmenlerin liderlik özellikleri sergiledikleri, kurum içerisinde çalışan diğer öğretmenler tarafından da teknoloji lideri olarak benimsendikleri, buna bağlı olarak da teknik destek sağlama, öğretim materyali sunma, derslerinde teknoloji kullanımına teşvik etme, teknoloji okuryazarlık bilgisini artırmaya çalışma ve öğretim programında teknoloji kullanımına yönelik danışmanlık rollerini de üstlendikleri tespit edilmiştir.

Bilgi iletişim teknolojileri ile lider desteği arasındaki ilişkiyi irdeleyen sınırlı sayıda bulunan çalışmalar ve kuramsal bilgilerden yola çıkarak bilgi iletişim teknolojileri kullanma kabiliyeti alt boyutlarının lider desteğine etkisini tespit etmek amacıyla kurgulanmış olan hipotezler aşağıda sunulmuştur.

Hipotez 5: Bilgi teknolojileri ĕgitimi, algılanan lider desteğini pozitif ve anlamlı olarak etkiler.

Hipotez 6: Bilgi teknolojileri stratejisi, algılanan lider desteğini pozitif ve anlamlı olarak etkiler. 
Hipotez 7: Haberleşme ve güncel takip uygulamaları, algllanan lider desteğini pozitif ve anlaml olarak etkiler.

Hipotez 8: İş zekâsı uygulamalarl, algılanan lider desteğini pozitif ve anlamlı olarak etkiler.

\subsection{Lider Desteği ve Yenilikçi Davranış}

Liderlik sürecine odaklanan çalışmalar dikkate alındığında söz konusu süreçteki çekirdek konunun "etkileme" ile bağlantılı olduğu ve bir organizasyonda başta işgörenler olmak üzere organizasyon yapısı ve kültürünün etkilenmesi olarak ifade edilmektedir (Moorhead ve Griffin, 2001). Bilindiği üzere liderin bir organizasyondaki yönetim fonksiyonlarını yerine getirirken göstermiş olduğu liderlik tarzı, söz konusu organizasyonlardaki çalışanların davranış ve tutumları üzerinde çeşitli değişimlere yol açmaktadır. Bu değişim organizasyona ait unsurların doğrudan veya dolaylı olarak tamamını etkilemektedir. Bu etkileşimin, liderin bireysel başarısı ve organizasyonun performansı üzerinde belirleyici role sahip olduğu düşünülmektedir.

Lider davranışlarının çeşitli boyutlarını açıklayarak liderin rolünün incelendiği çalışmalarda, liderlerin çalışanlara vizyonun benimsetilmesi, hedeflere odaklanma, destek sağlama ve geri besleme gibi çok çeşitli fonksiyonları ile destek sağladığı görülmektedir. Lider desteği çalışılmış bir çok destek kriterleri içerinde çalışanlar açısından en belirleyici olan kriterlerden biri olarak göze çarpmaktadır (Ackfeldt ve Coote, 2005; Podsakoff vd., 1996).

Lider desteğini konu alan çalışmalar incelendiğinde, örgüt içerisinde lider desteğinin çalışanlar ve örgüt açısından önemli sonuçlar meydana getirdiği bilinmektedir. Çalışanların stresinin azalmasında ve performanslarının artırmasında önemli etkileri bulunmaktadır (Rhoades ve Eisenberger, 2002). Yapılan bir araştırmada çalışanlar tarafından algılanan lider desteğinin, örgüt hedeflerinin elde edilmesinde çalışanların gönüllü katkılarını artırdığı tespit edilmiştir (Stinglhamber ve Vandenberghe, 2003).

Liderliğin yenilikçiliği etkileyen en önemli faktörlerden biri olduğu çeşitli çalışmalarda öne sürülmektedir (Osborne, 1998; Schin ve McClomb, 1998; Cummings ve O'Connell, 1978). Bu kapsamda incelendiğinde yenilikçilik ile ilgili araştırmalarda liderliğin yenilikçiliğe olan etkisi konusuna olan ilginin arttığı görülmektedir (Sastry, 1999; Howell ve Avolio, 1993). Bazı araştırmacılar lider desteği ile yenilikçilik davranışı arasındaki ilişkiyi anlayabilmek maksadıyla organizasyon içerisinde yenilik davranışlarını teşvik eden liderlik tarzlarını tanımlamaya çalışmışlar ve destekleyici, katılımcı, demokratik, işbirlikçi ve vizyon sahibi olma özellikleri taşıyan bir liderlik tarzının yenilikçiliği teşvik etmede etkili olduğu sonucuna ulaşmışlardır (Arıkan, 2017; Schin ve McClomb, 1998; Van de Ven, 1986; Farris, 1973).

Lider desteği ile yenilikçi davranış arasındaki ilişkiyi irdeleyen çalışmalar ve kuramsal bilgilerden yola çıkarak lider desteğinin çalışanların yenilikçi davranışlarına etkisini tespit etmek amacıyla kurgulanmış hipotez aşağıda sunulmuştur.

Hipotez 9: Lider desteği, çalışanların yenilikçi davranışlarını pozitif ve anlamlı olarak etkiler. 


\subsection{Bilgi ve İletişim Teknolojileri Kabiliyeti- Yenilikçi Davranış İlişkisinde Lider Desteğinin Aracılık Rolü}

Liderin; kültür, strateji, ödül sistemleri gibi örgütsel özelliklere, kaynaklara (Woodman, vd., 1993) veya çalışanların yaratıcı davranışlarını doğrudan etkilemesi gibi çeşitli etkilere sahip olduğu bilinmektedir (Oldham ve Cummings, 1996).

Bilgi ve iletişim teknolojileri kabiliyetinin çalışanların yenilikçi davranışları üzerinde bir etkisinin olduğu, söz konusu bu etkinin ise bazı aracı değişkenler ile çıktı değişkenlere yansıyabildiği düşünülmüştür. $\mathrm{Bu}$ düşünceden yola çıkılarak yapılan araştırmalardan elde edilen bulgulardan, işletmelerin sahip olduğu bilgi ve iletişim teknolojileri kabiliyetinin çalışanların yenilikçi davranışlarına olan etkisinde lider desteğinin aracılık rolü olabileceği düşünülmektedir. Literatürde işletmelerin sahip olduğu bilgi ve iletişim teknolojileri kabiliyetinin bireylerin yenilikçi davranışlarına etkisinde lider desteğinin aracılık rolünü inceleyen bir çalışmaya rastlanmamıştır. Bu ihtiyaçtan hareketle bilgi ve iletişim teknolojileri kabiliyetinin bireylerin yenilikçi davranışlarına etkisinde lider desteğinin aracılık rolünü tespit etmek amacıyla aşağıdaki hipotezler kurgulanmıştır.

Hipotez 10: Bilgi teknolojileri eğitiminin, çalışanların yenilikçi davranışlarına etkisinde lider desteğinin aracılık rolü vardır.

Hipotez 11: Bilgi teknolojileri stratejisinin, çalışanların yenilikçi davranışlarına etkisinde lider desteğinin aracılık rolü vardır.

Hipotez 12: Haberleşme ve güncel takip uygulamalarının, çalışanların yenilikçi davranışlarına etkisinde lider desteğinin aracılık rolü vardır.

Hipotez 13: İş zekâsı uygulamalarının, çalışanların yenilikçi davranışlarına etkisinde lider desteğinin aracılık rolü vardır.

\section{Araştırmanın Yöntemi}

$\mathrm{Bu}$ araştırmada, işletmelerin sahip oldukları bilgi ve iletişim teknolojileri kabiliyetlerinin (BİTK) dört alt boyutunun, çalışanların yenilikçi davranışları (YD) üzerine etkisi ve bu etkide lider desteğinin (LD) aracılık rolü belirlenmeye çalışılmış ve bu kapsamda ilk olarak çalışmanın örneklemi ve ölçeklerine ilişkin bilgilere yer verilmiştir. Örneklemden elde edilen veriler doğrultusunda araştırma modeli oluşturulmuş ve son olarak bu kurgulanan modele ilişkin analizler yapılmıştır. Buradan yola çıkılarak öncelikle araştırmaya konu olan her bir değişkenin doğrulayıcı faktör analizi yapılmış hemen akabinde söz konusu değişkenler arasındaki ilişkileri tespit etmek üzere korelasyon analizi gerçekleştirilmiştir. Araştırmanın hipotezleri ve aracılık etkileri yapılan hiyerarşik regresyon analizi ile test edilmiştir. Yapılan aracılık etkilerinin doğruluğunu sağlamak üzere Sobel testleri yapılmıştır. Yapılan bu analizler neticesinde elde edilen bulgular ile mevcut literatür arasında kıyaslamalar yapılarak yönetici/lider ve araştırmacılara çeşitli önerilerde bulunulmuştur.

Kuramsal bilgilerden ve görgül araştırmalardan yola çıkılarak oluşturulan araştırma modeli ve hipotezler Şekil 1' de sunulmuştur. 


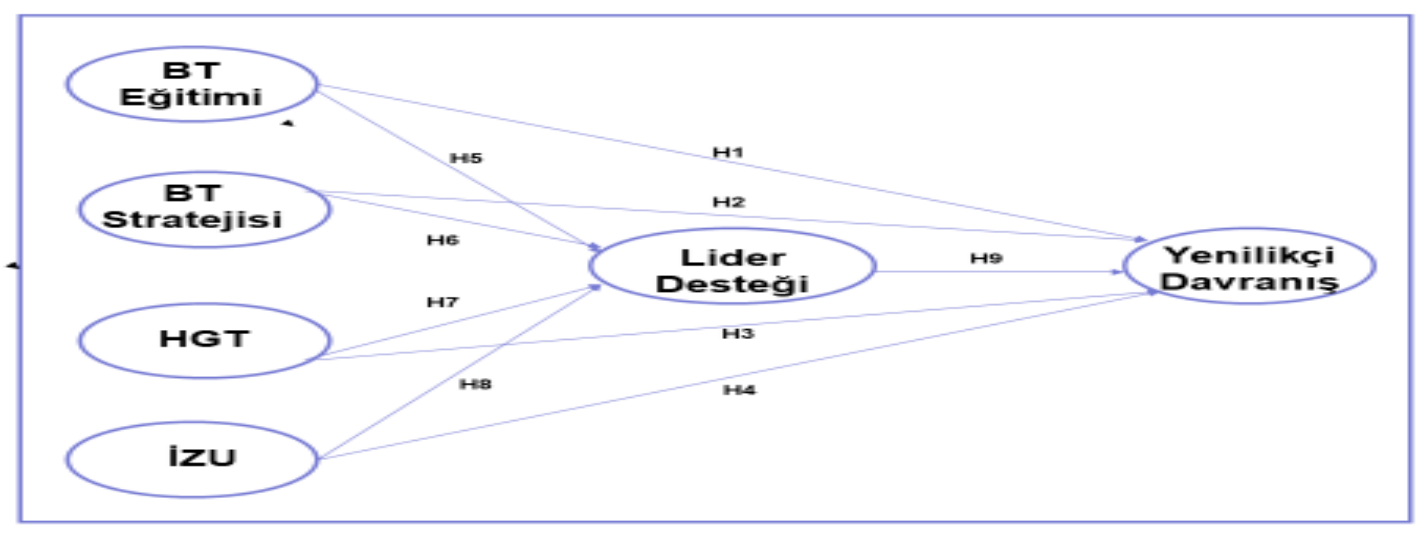

\section{Şekil 1. Araştırma Modeli ve Hipotezler}

\subsection{Araştırmanın Örneklemi}

Araştırma evreni, Ankara ilinde elektronik haberleşme sektöründe faaliyet göstermekte olan işletme çalışanları üzerine oluşturulmuştur. Yapılan incelemeler neticesinde söz konusu evrende yaklaşık 15000 kişi çalıştığ 1 belirlenmiştir. Ana evrenden $\% 95$ güvenilirlik sınırları içerisinde $\% 5^{\prime}$ lik bir hata payı kayda alınarak çalışmanın örneklem büyüklügü 375 kişi olarak hesap edilmiştir (Sekaran, 1992). Bu kapsamda kümelere göre örnekleme yöntemi aracilığıyla tesadüfî olarak seçilen işletmelerden toplam 1000 kişiye e-anket uygulaması yapılması planlanmıştır. Anketler, sadece üst düzey yöneticilere değil, yetki ve erişim hakları oranında işletme içerisinde tüm fonksiyon alanlarında görevli her kademedeki yöneticiler ve işgörenler tarafından da kullanılacak biçimde tasarlanmış ve işletmelere aktarılmıştır. Elektronik ortamda gönderilen anketlerden 596' S1 geri dönmüş, 568'i analiz yapmak için uygun bulunmuştur.

Araştırmaya katılım gösteren çalışanların \% 57'si erkek ( $n=324), \%$ 69,7'si $(\mathrm{n}=396)$ evlidir. Katılımcıların \% 18,4' ü $(\mathrm{n}=105)$ lise, \%64,7 $(\mathrm{n}=367)$ üniversite, \% 16,9 'u da $(\mathrm{n}=96)$ de lisansüstü eğitim derecesine sahiptir. Örneklemdeki katılımcıların, $\%$ 17,3'ü (n=98) 18-24 yaş, \% 32,9'u (n=186) 25-32 yaş, \% 34,3’ü $(n=194)$ 33-40 yaş ve $\% 15,8$ 'i de $(n=90) 41$ ve yukarı yaşlar arasındadır. Çalışanların \%25,5'i $(n=145) 3$ yıldan az, \%48,4'ü $(\mathrm{n}=275)$ 4-9 y1l aras1, \% 12,7'si $(\mathrm{n}=72)$ 10-15 y1l arası, \% 7,2'si $(\mathrm{n}=41)$ 16-21 yıl arası ve \%6,2' si de $(\mathrm{n}=35)$ de 22 ve yukarı yıl iş tecrübesine sahip oldukları belirlenmiştir.

\subsection{Araştırmanın Ölçekleri}

İşletmelerin sahip oldukları bilgi ve iletişim teknolojileri kabiliyetlerinin (BİTK) dört alt boyutunun, çalışanların yenilikçi davranışı (YD) üzerine etkisini ve söz konusu bu iki değişken arasındaki etkide lider desteğinin (LD) aracılık rolünü tespit etmeye yönelik olarak hazırlanan bu çalışmada kullanılan ölçeklere ilişkin bilgiler aşağıda sunulmuştur. Araştırmaya dahil edilen ölçeklerin SPSS paket programı ile Cronbach alfa güvenirlik katsayıları bulunmuş ve AMOS programı ile doğrulayıcı faktör analizleri yapılmıştır. 


\subsubsection{Bilgi ve İletişim Teknolojileri Kabiliyetleri (BİTK) Ölçeği}

İşletmelerde BİT kabiliyetlerinin ölçülmesi maksadıyla, Feeny ve Willcocks (1998) tarafından kullanılan ölçekten faydalanılarak, Türen ve arkadaşları (2013) tarafından geliştirilen dört boyutlu ölçek kullanılmıştır. Toplam yirmiüç sorudan oluşan ölçekte bilgi ve iletişim teknolojileri kabiliyetinin her bir boyutu farklı sorularla ölçülmeye çalışılmıştır. Sorulardan bazıları, "Çalışanlarımızın yeni bilişim teknolojilerine uyum sağlama ve kabullenme hızı giderek artmıştır.", "Bilişim Teknolojileri uygulama planımızın, genel işletme strateji ve planlart ile uyumu giderek artmıştır.", "Ofis Otomasyonu (Excel, Word, Power Point) kullanma etkinliğimiz artmıştır." ve "Bilgisayar destekli üretim ve tasarım etkinliğimiz artmıştır." şeklindedir. Araştırma kapsamında hazırlanan ölçekte katılımcı cevapları 5'li likert ölçeği yardımı ile alınmıştır (1=Kesinlikle katılmıyorum, 5=Kesinlikle katılıyorum). Çalışma ölçeğinin yapı geçerliliğini test etmek amacıyla AMOS programı ile keşfedici faktör analizi yapılmıştır. Yapılan analiz neticesinde toplanan verilerin bilgi ve iletişim teknolojileri kabiliyeti ölçeğinin tek faktörlü yapısına uyum sağladığı tespit edilmiştir. Ölçeğin faktör yüklerinin .70 ile .87 arasında olduğu, KMO analiz sonucu .90 ve Barlett testi anlamlı $(\mathrm{p}=.000)$ olarak tespit edilmiştir. Ardından AMOS paket programı ile doğrulayıcı faktör analizi yapılmış, verilerin ölçeğin tek faktörlü yapısına uyum sağladığı ve faktör yüklerinin .69 ile .82 arasında olduğu tespit edilmiştir. Bilgi ve iletişim teknolojileri kabiliyeti ölçeğinin uyum iyiliği değerleri araştırmaya dahil edilen diğer ölçekler ile birlikte Tablo 1'de sunulmuştur. Yapılan güvenirlik analizi sonucunda bilgi ve iletişim teknolojileri kabiliyeti ölçeğinin Cronbach alfa güvenirlik katsayısı .89 olarak bulunmuştur.

Bilgi ve iletişim teknolojileri kabiliyetinin alt boyutlarından ilki olan Bilgi Teknolojileri Ĕgitimi ölçeğinin yapı geçerliliğini test etmek amacıyla AMOS paket programı ile keşfedici faktör analizi yapılmış, analiz sonucunda ortaya çıkan verilerin bilgi teknolojileri eğitimi alt boyutunu belirlemeye yönelik hazırlanan ifadelerin tek faktörlü yapısına uyum sağladığı tespit edilmiştir. Analiz neticesinde 5 maddeli bilgi teknolojileri eğitimi ölçeğinin faktör yüklerinin .76 ile .81 arasında olduğu, KMO analiz sonucu .88 ve Barlett testi anlamlı $(\mathrm{p}=.000)$ olarak bulgulanmıştır. Ardından AMOS paket programı ile doğrulayıcı faktör analizi yapılmış, verilerin ölçeğin tek faktörlü yapısına uyum sağladığ 1 ve faktör yüklerinin .75 ile .79 arasında olduğu tespit edilmiştir. Bilgi teknolojileri eğitimi alt boyutuna ait uyum iyiliği değerleri diğer ölçeklerin uyum iyiliği değerleri ile birlikte Tablo 1'de sunulmuştur. Yapılan güvenirlik analizi neticesinde bilgi teknolojileri eğitimi alt boyutunun Cronbach alfa güvenirlik katsayıs1 .86 olarak tespit edilmiştir.

Bilgi ve iletişim teknolojileri kabiliyetinin alt boyutlarından ikincisi Bilgi Teknolojileri Stratejisidir. Söz konusu alt boyutu ölçmeye yarayan ifadelerin yap1 geçerliliğini tespit etmek maksadıyla keşfedici faktör analizi yapılmış, ortaya çıkan verilerin ölçeğin tek faktörlü yapısına uyum sağladığı tespit edilmiştir. Analiz neticesinde 6 maddeli BT Stratejisi alt boyutunun faktör yüklerinin .74 ile .79 arasında olduğu, KMO analiz sonucu .91 ve Barlett testi anlamlı $(p=.000)$ olarak belirlenmiştir. Ardından AMOS paket programı ile BT stratejisi alt boyutuna ilişkin doğrulayıcı faktör analizi yapılmış, çıkan veriler ölçeğin tek faktörlü yapısına uyum sağladığını tespit edilmiştir. Ölçeğin faktör yüklerinin .77 ile .83 arasında olduğu tespit edilmiştir. BT stratejisi alt boyutuna ait uyum iyiliği değerleri diğer ölçekler ile birlikte yine Tablo 
1'de sunulmuştur. Yapılan güvenirlik analizi sonucunda BT stratejisi alt boyutunun Cronbach alfa güvenirlik katsayısı .88 olarak tespit edilmiştir.

Bilgi ve iletişim teknolojileri kabiliyetinin alt boyutlarından üçüncü boyut olan Haberleşme ve Güncel Takip Uygulamaları ölçeğinin yapı geçerliliğini test etmek amacıyla keşfedici faktör analizi yapılmış, çıkan sonuçlara göre elde edilen verilerin haberleşme ve güncel takip uygulamaları alt boyutunu temsil eden ifadelerin ölçeğin tek faktörlü yapısına uyum gösterdiği tespit edilmiştir. Yapılan analiz neticesinde söz konusu alt boyutu temsil eden 6 maddenin faktör yüklerinin .77 ile .86 arasında olduğu, KMO analiz sonucu .86 ve Barlett testi anlamlı $(p=.000)$ olarak tespit edilmiştir. Ardından AMOS paket programı ile haberleşme ve güncel takip uygulamaları alt boyutunun doğrulayıcı faktör analizi yapılmış, çıkan veriler ile ölçeğin tek faktörlü yapıya uyum sağladığı ve faktör yüklerinin .73 ile .79 arasında olduğu tespit edilmiştir. Haberleşme ve güncel takip uygulamaları alt boyutuna ait uyum iyiliği değerleri diğer ölçeklerinki ile birlikte Tablo 1'de verilmiştir. Yapılan güvenirlik analizi sonucunda ölçeğin HGT alt boyutunun Cronbach alfa güvenirlik katsayısı .88 olarak tespit edilmiştir.

Bilgi ve iletişim teknolojileri kabiliyetinin alt boyutlarından sonuncusu olan $\dot{\boldsymbol{I}} \boldsymbol{s}$ Zekâsı Uygulamaları ölçeğinin yapı geçerliliğini test etmek amacıyla keşfedici faktör analizi yapılmış ve analiz sonucunda elde edilen verilerin iş zekası uygulamaları ifadelerinin ölçeğin tek faktörlü yapısına uyum sağladığı tespit edilmiştir. Analiz sonucunda toplam 6 maddeden oluşan IZU ölçeğinin faktör yüklerinin .81 ile .87 arasında olduğu, KMO analiz sonucu .92 ve Barlett testi anlamlı $(\mathrm{p}=.000)$ olarak tespit edilmiştir. Hemen akabinde AMOS paket programı aracılığıyla ölçeğe doğrulayıcı faktör analizi yapılmış, çıkan verilerin ölçeğin tek faktörlü yapısına uyum sağladığı ve faktör yüklerinin .78 ile .86 arasında olduğu tespit edilmiştir. İş zekası uygulamaları alt boyutunu temsil eden ifadelerin uyum iyiliği değerleri diğer ölçeklerinki ile birlikte Tablo 1'de gösterilmiştir. Yapılan güvenirlik analizi sonucunda ölçeğin Cronbach alfa güvenirlik katsayısı .85 olarak bulunmuştur.

\subsubsection{Lider desteği (LD) Ölçeği}

İşletmelerde çalışanlarda algılanan lider desteği düzeyini belirlemek üzere Netemeyer ve arkadaşları (1997) tarafından geliştirilen ve Akkoç ve arkadaşları (2011) tarafından Türkçe geçerlemesi yapılan ölçek kullanılmıştır. Toplam 5 ifadeden oluşan bu ölçekte sorular "Çalıştığım işletmede bizlere yöneticimiz tarafindan destek verilmektedir" ve "Yöneticim işler zorlaştığ durumlarda bile güvenilirdir." ş̧eklindedir. Araştırma kapsamında hazırlanan ölçekte katılımcı cevapları 5'li likert ölçeği yardımı ile alınmıştır (1=Kesinlikle katılmıyorum, 5=Kesinlikle katılıyorum). Çalışma ölçeğinin yapı geçerliliğini test etmek amacıyla AMOS programı ile keşfedici faktör analizi yapılmıştır. Analiz neticesinde ortaya çıkan değerlerin lider desteği ölçeğinin tek faktörlü yapısına uyum sağladığı belirlenmiştir. Söz konusu ölçeğin faktör yüklerinin .73 ile .82 arasında olduğu, KMO analiz sonucunun .83 ve Barlett testinin ise anlamlı $(\mathrm{p}=.000)$ olduğu bulgulanmıştır. Akabinde gerçekleştirilen AMOS paket programı ile ölçeğin doğrulayıcı faktör analizi yapılmış ve verilerin lider desteği ölçeğinin tek faktörlü yapısına uyum sağladığı ve faktör yüklerinin .69 ile .74 arasında olduğu tespit edilmiştir. Lider desteği ölçeğinin uyum iyiliği değerleri araştırmaya konu olan diğer ölçeklerinki ile birlikte yine Tablo 1'de sunulmuştur. Yapılan güvenirlik analizi 
sonucunda lider desteği ölçeğinin Cronbach alfa güvenirlik katsayısı .91 olarak bulunmuştur.

\subsubsection{Yenilikçi davranış Ölçeği (YD)}

Çalışanların yenilikçi davranış göstermelerinin ölçülmesinde Scott ve Bruce. (1994) tarafından geliştirilen ve Çalışkan ve arkadaşları (2011) tarafından Türkçe geçerlemesi yapılan ölçek kullanılmıştır. Ölçek 6 sorudan oluşmaktadır. Ölçek soruları "Yeni teknolojiler, süreçler, teknikler araştırırım ve fikirler üretirim" ve "Yenilikçiyim" şeklindeki ifadelerden oluşmaktadır. Araştırma kapsamında hazırlanan ölçekte katılımcı cevapları 5'li likert ölçeği yardımı ile alınmıştır (1=Kesinlikle katılmıyorum, $5=$ Kesinlikle katılıyorum). Çalışmada ölçeğin yap1 geçerliliğini test etmek amacıyla keşfedici faktör analizi yapılmış ve çıkan veriler ışığında ölçeğin tek faktörlü yapısına uyum sağladığı tespit edilmiştir. Ölçeğin faktör yüklerinin .76 ile .83 arasında olduğu, KMO analiz sonucu .92 ve Barlett testi anlamlı $(\mathrm{p}=.000)$ olarak belirlenmiştir. Ardından AMOS paket programı kullanılarak doğrulayıcı faktör analizi yapılmış, verilerin ölçeğin tek faktörlü yapısına uyum sağladığı ve faktör yüklerinin .67 ile .76 arasında olduğu tespit edilmiştir. Yenilikçi davranış ölçeğine ilişkin uyum iyiliği değerleri diğer ölçeklerinki ile birlikte Tablo 1'de sunulmuştur. Yapılan güvenirlik analizi sonucunda yenilikçi davranış ölçeğinin Cronbach alfa güvenirlik katsayısı .93 olarak bulunmuştur.

\section{BULGULAR}

Araştırma kapsamında örneklemden elde edilen verilere SPSS ve AMOS paket programı kullanılarak analizler yapılmıştır. Bu kapsamda, ilk olarak araştırmada kullanılan ölçeklerin doğrulayıcı faktör analizleri (CFA) yapılmıştır. Doğrulayıcı faktör analizi (CFA) sonuçları aşağıda Tablo 1' de tüm ölçekler ve alt boyutları şeklinde bir arada sunulmuştur.

Tablo 1. Doğrulayıcı Faktör Analizi Sonucunda Ölçeklerin Uyum İyiliği Değerleri

\begin{tabular}{|c|c|c|c|c|c|c|c|}
\hline Değişkenler & $\begin{array}{c}\text { CMIN/DF } \\
<5\end{array}$ & $\begin{array}{l}\text { GFI } \\
>.85\end{array}$ & $\begin{array}{l}\text { AGFI } \\
>.80\end{array}$ & $\begin{array}{l}\text { CFI } \\
>.90 \\
\end{array}$ & $\begin{array}{l}\text { NFI } \\
>.90\end{array}$ & $\begin{array}{r}\text { TLI } \\
>.90 \\
\end{array}$ & $\begin{array}{c}\text { RMSEA } \\
<.08\end{array}$ \\
\hline 1. BT Eğitimi (BTE) & 3.3 & .96 & .97 & .99 & .92 & .96 & .02 \\
\hline 2. BT Stratejisi (BTS) & 3.5 & .93 & .98 & .95 & .96 & .99 & .03 \\
\hline $\begin{array}{l}\text { 3. Haberleşme ve güncel takip } \\
\text { uygulamaları (HGT) }\end{array}$ & 3.1 & .91 & .93 & .95 & .97 & .99 & .04 \\
\hline $\begin{array}{l}\text { 4. İş zekâsı uygulamaları } \\
\text { (İZU) }\end{array}$ & 2.4 & .94 & .97 & .98 & .98 & .99 & .05 \\
\hline 5. Lider Desteği (LD) & 3.2 & .95 & .98 & .96 & .98 & .98 & .05 \\
\hline 6. Yenilikçi Davranış (YD) & 3.9 & .94 & .99 & .94 & .98 & .97 & .01 \\
\hline
\end{tabular}

Not: Uyum iyiliği değer aralıkları “kabul edilebilir” standartlara göre düzenlenmiştir.

Araştırma analizinin ikinci aşaması kapsamında, işletmelerin sahip oldukları Bilgi ve İletişim Teknolojileri Kabiliyetinin, BT Eğitimi, BT Stratejisi, Haberleşme ve Güncel Takip Uygulamaları ve İş Zekâsı Uygulamaları alt boyutları ile lider desteği ve yenilikçi davranışa ilişkin elde edilen verilerin ortalamaları, standart sapmaları ve değişkenler arasındaki korelasyonlara bakılmıştır. Söz konusu araştırmaya ilişkin bulgular Tablo 2'de gösterilmiştir. Analizin üçüncü aşamasında ise, Baron ve Kenny (1986) tarafından öne sürülen üç aşamalı hiyerarşik regresyon analizi ile bilgi ve iletişim teknolojileri kabiliyeti ve alt boyutlarının yenilikçi davranış üzerindeki etkisinde lider desteğinin aracılık etkisi araştırılmıştır. 
Tablo 2. Verilere ilişkin Ortalama, Standart Sapma ve Korelasyon Değerleri

\begin{tabular}{lllllllll}
\hline & Ort. & S.S. & BTE & BTS & HGT & IZU & LD & YD \\
\hline 1. BTE & 3.43 & 1.57 & $\mathbf{( . 8 6 )}$ & & & & & \\
2. BTS & 3.26 & 1.74 & $.63^{* *}$ & $\mathbf{( . 8 8 )}$ & & & & \\
3. HGT & 3.14 & 1.45 & $.72^{* *}$ & $.70^{* *}$ & $\mathbf{( . 8 8 )}$ & & & \\
4. IZU & 3.06 & 1.37 & $.70^{* *}$ & $.72^{* *}$ & $.69^{* *}$ & $\mathbf{( . 8 5 )}$ & & \\
5. LD & 3.37 & 1.20 & $.78^{* *}$ & $.76^{* *}$ & $.79^{* *}$ & $.82^{* *}$ & $\mathbf{( . 9 1 )}$ & \\
6. YD & 3.56 & 1.05 & $.83^{* *}$ & $.81^{* *}$ & $.82^{* *}$ & $.85^{* *}$ & $.87^{* *}$ & $\mathbf{( . 9 3 )}$ \\
\hline
\end{tabular}

** $\mathrm{p}<.01$ Not: Cronbach alfa güvenirlik katsayıları parantez içinde verilmiştir.

Yukarıda Tablo 2'de görüldüğü üzere araştırmaya konu edilen bağımsız değişkenler olan bilgi ve iletişim teknolojileri kabiliyeti ve tüm alt boyutları ile lider desteğinin ve bağımlı değişken yenilikçi davranış arasında anlamlı ilişkiler bulunmaktadır. Bu sebeple değişkenler arasında önemli etkiler olduğunu söylemek mümkün görünmektedir. Araştırmanın analizi kapsamında oluşturulan modelde çoklu doğrusal bağlantı sorunu olup olmadığını tespit etmek amaciyla doğrudaşlık (collinearity) da incelenmiştir. Elde edilen tolerans ve VIF değerleri bağımsız değişkenler arası çoklu bağlantı olmadığını doğrulayan sonuçlar vermiştir (Tolerans > $.2, \mathrm{VIF}<10)$.

Bilgi ve İletişim Teknolojileri Kabiliyetinin, Bilgi Teknolojileri Eğitimi (BTE), Bilgi Teknolojileri Stratejisi (BTS), Haberleşme ve Güncel Takip Uygulamaları (HGT) ve İş Zekâsı Uygulamaları (İZU) boyutlarının çalışanların yenilikçi davranışları (YD) üzerindeki etkisini belirlemek ve söz konusu bu etkide lider desteğinin (LD) aracılık rolünü tespit etmek maksadıyla, Baron ve Kenny (1986) tarafından öne sürülen üç aşamalı regresyon analizi yapılmıştır. $\mathrm{Bu}$ yönteme göre, araştırmaya konu edilen bağımsız değişkenin bağımlı değişken ve aracı değişken üzerinde bir etkisi olmalıdır. Daha sonraki aşamada ise aracı değişken bağımsız değişkenle birlikte regresyon analizine dâhil edildiğinde, bağımsız değişkenin bağımlı değişken üzerindeki regresyon katsayısı düşerken, aracı değişkenin de bağımlı değişken (YD) üzerinde anlamlı etkisi devam etmelidir. Bu kapsamda Lider Desteği düzeyinin aracılık rolünü tespit etmek maksadıyla, BTE-LD, YD; BTS-LD, YD; HGT-LD, YD ve IZZU-LD, YD arasındaki ilişskiler hiyerarşik regresyon analizi yardımıyla incelenmiş, ardından Sobel testleri yapılmıştır. Aracılık testine ilişkin ortaya çıkan bulgular Tablo 3, 4, 5 ve 6' da sunulmuştur.

Aracılık testi kapsamında yapılan ilk aşamada bağımsız değişkenlerden biri olan Bilgi Teknolojileri Eğitimi ile Yenilikçi Davranış arasındaki ilişkiler incelenmiştir. Söz konusu aşamanın ilk basamağında BTE' nin YD' yi $(\beta=.83, p<.001)$ anlamlı olarak etkilediği tespit edilmiştir. Aşamanın ikinci basamağında BTE' nin aracılığı araştırılan LD' ye olan etkisi incelenmiştir. Yapılan analiz neticesinde BTE' nin LD' yi anlamlı olarak etkilediği $(\beta=.78, p<.001)$ tespit edilmiştir. Aynı zamanda yine bu basamakta aracılığ 1 araştırılan LD' nin YD' ye olan etkilerine de bakılarak rapor edilmişstir. LD' nin YD' yi $(\beta=.87, p<.001)$ anlamlı olarak etkilediği tespit edilmiştir. Yapılan aşamanın son basamağında ise BTE ve aracılığı araştırılan LD birlikte analize dahil 
edilmiş ve YD üzerindeki etkilerine bakılmıştır. Bu analiz neticesinde BTE' nin LD ile birlikte analize dahil edilmesiyle YD üzerindeki etkisi devam etmiş ve azalmış ( $\beta=$ $.47, p<.001)$, LD' nin de YD üzerindeki etkisi devam etmiştir $(\beta=.59, p<.001)$. Tüm bu şartların sağlanmasıyla birlikte aracılık etkisini doğrulamak amacıyla Sobel testi gerçekleştirilmiş ve test sonucu anlamlı bulunmuştur $(\mathrm{z}=7.9, \mathrm{p}<.001)$. Bu sonuç BTE'nin YD'ye etkisinde LD' nin kısmi aracılık rolü üstlendiğini ortaya koymuştur. Bu bölüm analizleri sonucunda H1, H5, H9 ve aracılık hipotezi olan H10'un desteklendiği görülmektedir.

Yapılan aracılık analizinin ikinci aşamasında ikinci bağımsız değişkenlerden biri olan BT Stratejisi ile yenilikçi davranış arasındaki ilişkilere bakılmıştır. Bu aşamanın ilk basamağında BTS' nin YD' yi $(\beta=.81, \mathrm{p}<.001)$ anlamlı olarak etkilediği görülmüştür. İkinci basamakta BTS' in aracılığı araştırılan LD' ye olan etkisi araştırılmıştır. Analiz neticesinde BTS' nin LD' yi anlamlı olarak etkilediği $(\beta=.76, p<.001)$ bulgulanmıştır. $\mathrm{Bu}$ aşamanın son basamağında ise BTS ve aracılığ edilmiş ve YD üzerindeki etkilerine bakılmıştır. Bu analiz neticesinde BTS' nin LD ile birlikte analize dahil edilmesiyle YD üzerindeki etkisi devam etmiş ve azalmış $(\beta=$ $.39, \mathrm{p}<.001)$, LD' nin de YD üzerindeki etkisi devam etmiştir $(\beta=.54, \mathrm{p}<.001)$. Bütün bu şartların sağlanması ile birlikte aracılık etkisini doğrulamak maksadıyla Sobel testi gerçekleştirilmiş ve test sonucu anlamlı bulunmuştur $(\mathrm{z}=7.1, \mathrm{p}<.001)$. Bu sonuç neticesinde de BTS' nin YD' ye etkisinde LD' nin kısmi aracılık rolü üstlendiği belirlenmiştir. Bu bölümde yapılan analizler neticesinde H2, H6 ve aracılık hipotezi olan H11' in desteklendiği görülmektedir.

Analizin üçüncü aşamasında bağımsız değişkenlerden bir diğeri olan Haberleşme ve Güncel Takip Uygulamaları ile Yenilikçi Davranış arasındaki ilişkilere bakılmıştır. Bu aşamanın ilk basamağında HGT' nin YD' yi $(\beta=.82, p<.001)$ anlamlı olarak etkilediği tespit edilmiştir. İkinci basamakta HGT' nin aracılığı araştırılan LD' ye olan etkisi irdelenmiştir. Yapılan analiz neticesinde HGT' nin LD' yi anlamlı olarak etkilediği $(\beta=.79, \mathrm{p}<.001)$ belirlenmiştir. $\mathrm{Bu}$ aşamanın son basamağında ise HGT ve aracılığı araştırılan LD birlikte analize dahil edilmiş ve YD üzerindeki etkilerine bakılmıştır. Bu analiz neticesinde HGT' nin LD $^{\prime}$ ile birlikte analize dahil edilmesiyle YD üzerindeki etkisi devam etmiş ve azalmış $(\beta=.28, p<.001)$, LD' nin de YD üzerindeki etkisi devam etmiştir $(\beta=.61, p<.001)$. Söz konusu bu şartların sağlanması ile birlikte aracılık etkisini doğrulamak amaciyla Sobel testi gerçekleştirilmiş ve test sonucu anlamlı bulunmuştur $(\mathrm{z}=7.6, \mathrm{p}<.001) . \mathrm{Bu}$ sonuç HGT'nin YD' ye etkisinde LD' nin kısmi aracılık rolü üstlendiğini göstermektedir. Bu bölüm analizleri sonucunda $\mathrm{H3}, \mathrm{H} 7$ ve aracılık hipotezi olan H12' nin desteklendiği görü̈lmektedir.

Son olarak, bağımsız değişkenlerden bir diğeri olan İş Zekâsı Uygulamaları ile Yenilikçi Davranış arasındaki ilişkilere bakılmıştır. Bu aşamanın ilk basamağında İZU' nun YD' yi $(\beta=.85, p<.001)$ anlamlı olarak etkilediği tespit edilmiştir. İkinci basamakta IZU'nun aracılığı araştırılan LD' ye olan etkisi incelenmiştir. Yapılan analiz neticesinde IZU' nun LD' yi anlamlı olarak etkilediği $(\beta=.82, p<.001)$ tespit edilmiştir. $\mathrm{Bu}$ aşamanın son basamağında ise IZU ve aracılı̆̆ 1 araştırılan LD birlikte analize dahil edilmiş ve YD üzerindeki etkilerine bakılmıştır. Bu analiz sonucunda İZU' nun LD ile birlikte analize sokulmasıyla YD üzerindeki etkisi devam etmiş ve azalmış $(\beta=.34, p<.001)$, LD' nin de YD üzerindeki etkisi devam etmiştir $(\beta=.48$, $\mathrm{p}<.001)$. Tüm bu şartların sağlanması ile birlikte aracılık etkisini doğrulamak amacıyla 
Sobel testi gerçekleştirilmiş ve test sonucu anlamlı bulunmuştur $(\mathrm{z}=8.1, \mathrm{p}<.001)$. Bu sonuç IZU' nun YD' ye etkisinde, LD' nin kısmi aracılık rolü üstlendiğini göstermektedir. Bu bölüm analizleri sonucunda $\mathrm{H4}$, $\mathrm{H8}$ ve aracılık hipotezi olan H13' ün desteklendiği görülmektedir. Bu sonuçla birlikte, regresyon analizleri ile test edilen toplam 13 hipotezin tamamının destek bulduğunu söylemek mümkün görünmektedir.

Tablo 3. Aracılık Testi Bulguları (BTE-LD-YD)

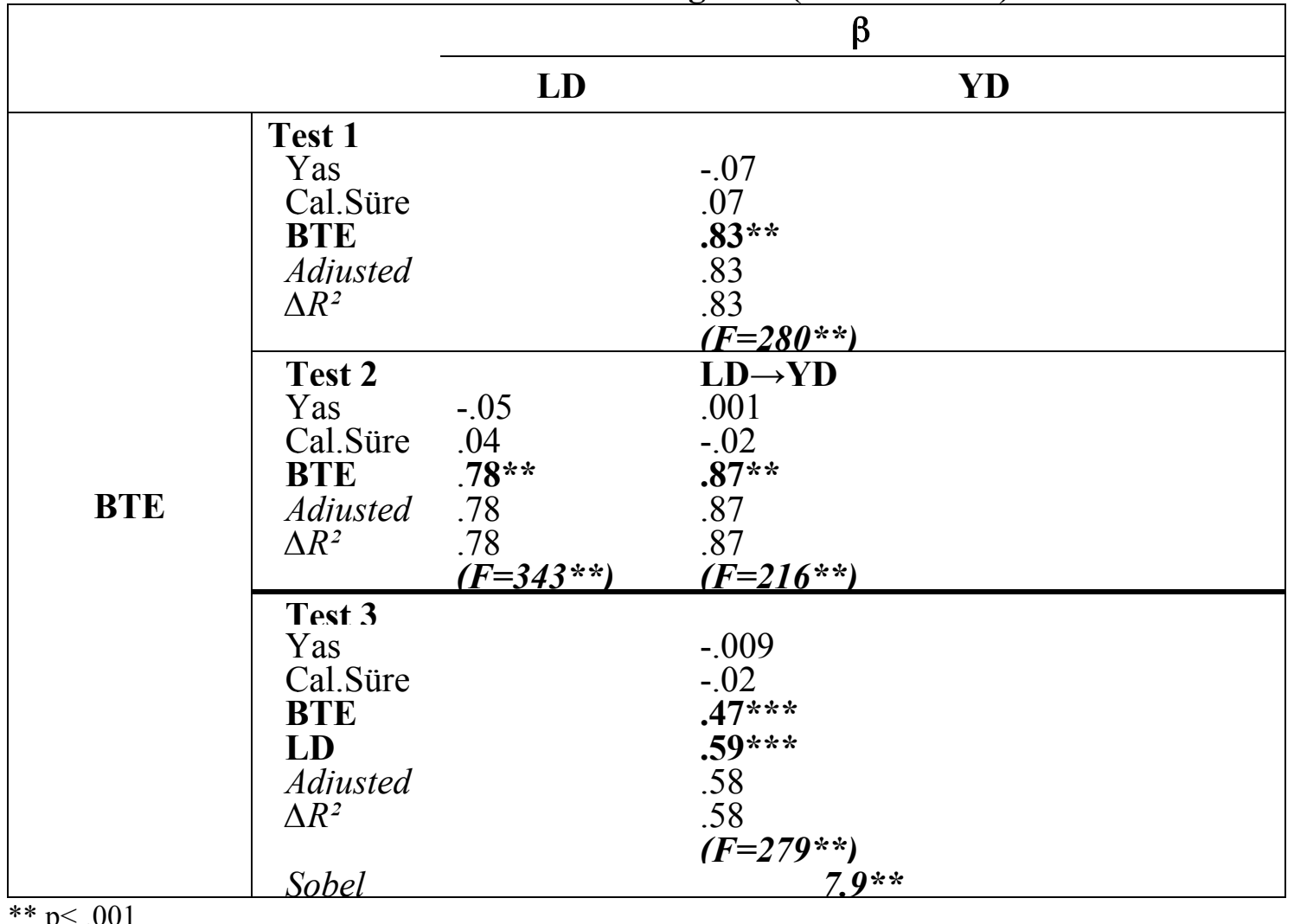

Tablo 4. Aracılık Testi Bulguları (BTS-LD-YD)

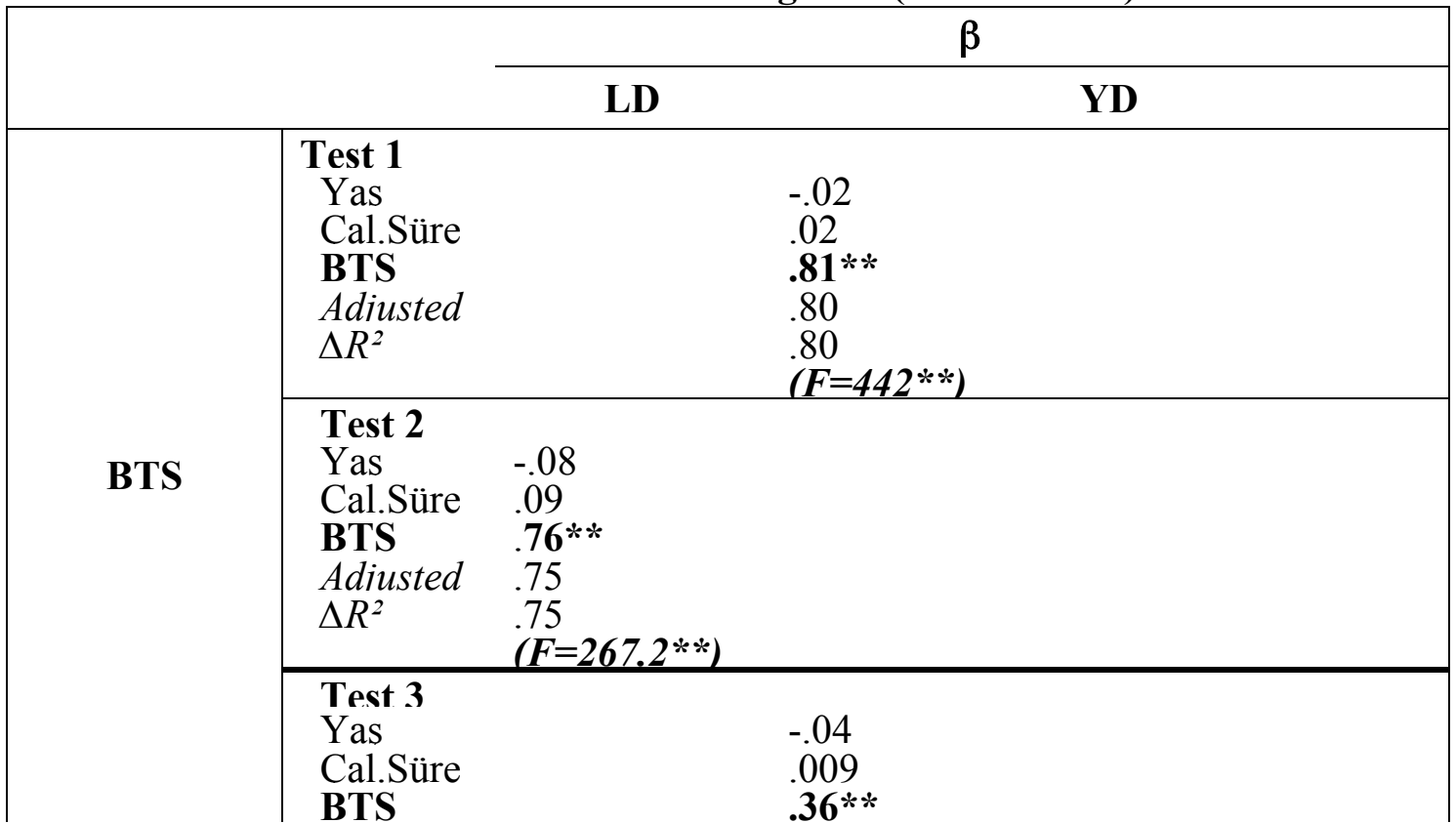


N. Ü. Pekkan - A. Çalışkan 10/1 (2018) 358-381

\begin{tabular}{|l|ll|} 
LD & $.54 * *$ \\
& Adiusted & .53 \\
$\Delta R^{2}$ & .53 \\
& Sobel & $(\boldsymbol{F}=189 * *)$ \\
& & $7.1 * *$ \\
\hline
\end{tabular}

$* * \mathrm{p}<.001$

Tablo 5. Aracılık Testi Bulguları (HGT-LD-YD)

\begin{tabular}{|c|c|c|c|}
\hline & & & $\beta$ \\
\hline & & LD & YD \\
\hline 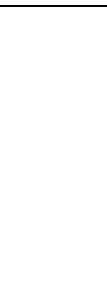 & $\begin{array}{l}\text { Test } 1 \\
\text { Yas } \\
\text { Cal.Süre } \\
\text { HGT } \\
\text { Adiusted } \\
\Delta R^{2}\end{array}$ & & $\begin{array}{l}-.07 \\
.04 \\
.82 * * \\
.82 \\
.82 \\
(\boldsymbol{F}=299 * *)\end{array}$ \\
\hline HGT & $\begin{array}{l}\text { Test } 2 \\
\text { Yas } \\
\text { Cal.Süre } \\
\text { HGT } \\
\text { Adiusted } \\
\Delta R^{2}\end{array}$ & $\begin{array}{l}-.07 \\
.08 \\
.79 * * \\
.79 \\
.78 \\
(F=405 * *)\end{array}$ & \\
\hline & $\begin{array}{l}\text { Test } 3 \\
\text { Yas } \\
\text { Cal.Süre } \\
\text { HGT } \\
\text { LD } \\
\text { Adiusted } \\
\Delta R^{2} \\
\text { Sobel }\end{array}$ & & $\begin{array}{l}-.06 \\
.02 \\
.28 * * \\
.61 * * \\
.60 \\
.60 \\
(F=356 * *) \\
7.6 * *\end{array}$ \\
\hline
\end{tabular}

$* * \mathrm{p}<.001$

Tablo 6. Aracılık Testi Bulguları (IZU-LD-YD)

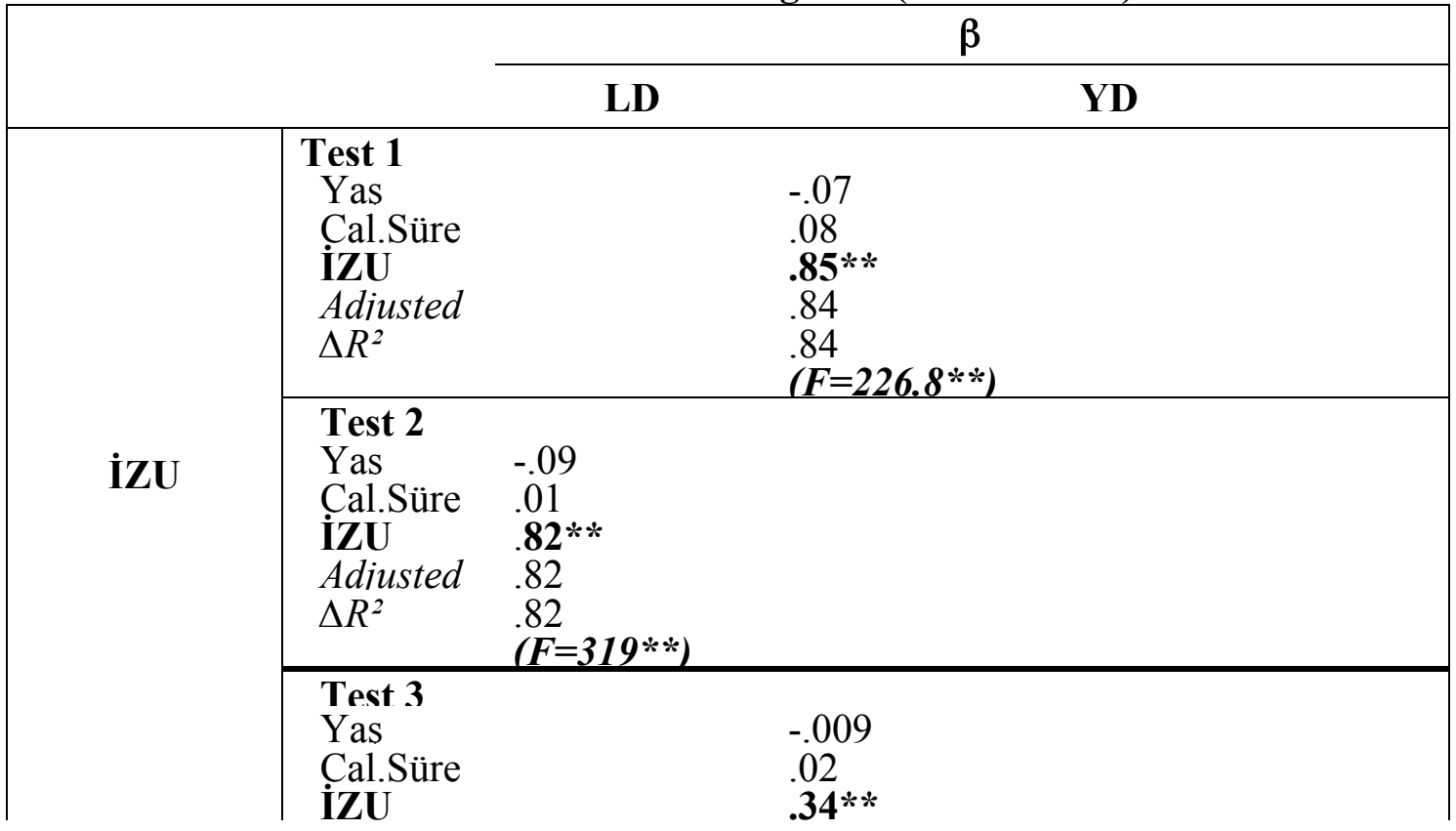




\begin{tabular}{|l|ll|} 
& LD & $\mathbf{4 8 * *}$ \\
& Adiusted & 47 \\
$\Delta R^{2}$ & 47 \\
& Sobel & $\mathbf{( F = 1 8 6 * * )}$ \\
& $\mathbf{8 . 1 * *}$ \\
\hline
\end{tabular}

$* * \mathrm{p}<.001$

\section{TARTIŞMA VE SONUÇ}

$\mathrm{Bu}$ çalışma ile bilgi teknolojileri eğitimi, bilgi teknolojileri stratejisi, haberleşme ve güncel takip uygulamaları ve iş zekası uygulamaları olmak üzere dört alt boyuttan oluşan bilgi ve iletişim teknolojileri kabiliyetinin çalışanların yenilikçi davranışı üzerindeki etkileri ve söz konusu bu iki değişkenin arasındaki etkide lider desteğinin aracılık rolü tespit edilmeye çalışılmıştır. Bu amaçla Ankara'da elektronik haberleşme sektöründe faaliyet gösteren işletme çalışanları üzerinde uygulamalı bir araştırma gerçekleştirilmiştir. Bu araştırma ile analize dâhil edilen bilgi ve iletişim teknolojileri kabiliyeti ve dört alt boyutunun yenilikçi davranış üzerindeki etkileri regresyon analizi yardımıyla açıklanmaya çalışılmıştır. Yapılan araştırma ile çalışanlara ilişkin bilgi ve iletişim teknolojileri kabiliyeti-lider desteği ve yenilikçi davranış ilişkisine yönelik açılayıcı bulgular elde edilmiştir.

Analiz sonuçları incelendiğinde; bilgi ve iletişim teknolojileri kabiliyetinin yenilikçi davranış ile ilişkili olduğu ve yenilikçi davranışı bilgi teknolojileri eğitimi, bilgi teknolojileri stratejisi, haberleşme ve güncel takip uygulamaları ve iş zekası uygulamaları olarak tüm alt boyutlarıyla anlamlı ve pozitif yönlü olarak etkilediği belirlenmiştir. Literatür taraması neticesinde yerli ve yabancı alan yazında bu üç değişkeni bir arada inceleyen çalışmalara rastlanmamıştır. Ancak bilgi ve iletişim teknolojileri kullanımının örgütsel çıktılara olumlu yansımasını gözler önüne seren ve özellikle örgütler üzerindeki yarattığı değişime yönelik çok sayıda çalışmaya rastlamak mümkündür. Yenilikçi davranışın olumlu bir örgütsel çıktı olduğu göz önüne alındığında bu çalışmanın söz konusu çalışmaların sonuçlarını destekleyecek nitelikte olduğunu söylemek mümkün görünmektedir. Dolayısıyla çalışma bulgularının benzer değişkenler içeren çalışmalar ile uyumlu olduğu görülmektedir (Aksoy, 2005; Dong 2006; Bükeç, 2007; Melville., 2010; Türen vd., 2013).

Araştırmanın bir diğer sonucu olarak lider desteğinin çalışanların yenilikçi davranışı ile ilişkili olduğu ve lider desteğinin çalışanların yenilikçi davranışını pozitif ve anlamlı olarak artırdığı tespit edilen bulgulardandır. Bu bulgu benzer araştırmalar ile uyumludur (West, vd., 2003; Howell ve Avolio, 1993; Kisfalvi ve Pitcher, 2003; Jung vd., 2003; Elenkov ve Manev 2009).

Bilgi ve iletişim teknolojileri kabiliyetinin; çalışanların yenilikçi davranış biçimi geliştirmelerinde ve yeni fikir ve önerilerini örgüt amaçları doğrultusunda etkili bir biçimde uygulamaya geçirmelerinde önem arz ettiği ve işletmenin sahip olduğu bilgi ve iletişim teknolojilerinin işletme tarafindan doğru bir biçimde kullanma yetisine sahip olmanın yoğun rekabet koşulları altında diğer işletmeler arasından sıyrılmada önemli bir kazanım olarak görülmesi gerektiği ortaya çıkmaktadır. Bu kapsamda bir işletmenin sahip olduğu bilgi ve iletişim teknolojilerini etkili bir biçimde kullanma becerisinin yüksek olması, çalışanların örgüt içerisinde göstereceği yenilikçi davranışlarının da artmasını sağlayacaktır. Nitekim bu araştırmanın sonuçları da bu beklentileri doğrular 
tarzda bilgi ve iletişim teknolojileri kabiliyetinin yenilikçi davranışı anlamlı ve pozitif yönlü olarak etkilediğini göstermektedir.

Bilgi ve iletişim teknolojileri kabiliyetinin çalışanların yenilikçi davranışına etkisinin olduğu, bu etkinin bazı değişkenler aracılı̆̆ dolayısıyla da çıktı değişkenlere yansıyabildiği düşünülmüştür. Bu noktadan hareketle bilgi ve iletişim teknolojileri kabiliyeti alt boyutlarının çalışanların yenilikçi davranışlarına olan etkisinde lider desteğinin aracılık rolü araştırılmıştır. Bu kapsamda elde edilen bulgulardan bilgi ve iletişim teknolojileri kabiliyetinin dört alt boyutunun yenilikçi davranışa etkisinde lider desteğinin kısmi aracılık rolünün olduğu tespit edilmiştir. Sonuç olarak, bir işletmenin sahip olduğu bilgi ve iletişim teknolojileri kabiliyetinin yüksekliği ve bu sahip olunan kabiliyetin örgüt içerisindeki bilgilerle birleştirilmesinde lider desteğinin olması çalışanların yenilikçi davranış düzeyini etkilemektedir. $\mathrm{Bu}$ kapsamda günümüz lider ve yöneticilerine söz konusu araştırma konusu ile ilgili çeşitli tavsiyelerde bulunmak mümkün görünmektedir. İşletmelerin sahip oldukları bilgi ve iletişim teknolojilerinin örgüt yararına olacak şekilde çalışanların fikir ve önerilerinin de dikkate alınarak kullanılması örgüt içerisindeki yenilikçi davranışları arttıracaktır. Yenilikçi davranışların artmasında destek olgusunun son derece önemli olduğu göz önünde bulundurulmalı ve liderlerin bu tür uygulamaları benimsemeleri gerektiği unutulmamalıdır. Yaratıcılığı yüksek, kendini örgütündeki olaylara karşı müdahil olmuş hisseden, fikirlerine önem verildiğini ve yenilikçi düşüncelerinin desteklendiğini düşünen çalışanların, uzun vadede örgüt performansını da artırıcı etkiye sahip olacağı bilinmelidir.

$\mathrm{Bu}$ çalışmanın, bilgi ve iletişim teknolojileri kabiliyeti, lider desteği ve yenilikçi davranış kavramlarını ilk olarak bir arada araştırmaya dâhil etmesi sebebiyle, bilimsel birikime ve meslek hayatına sağlayacağı katkı bakımından özgün bir değeri bulunmaktadır.

Her araştırma da olduğu üzere bu araştırmanın da bazı kısıtları bulunmaktadır. Öncelikle ilk olarak, araştırmanın elektronik haberleşme sektöründe yapılmış olması diğer sektörlere araştırma kapsamında yer verilmemesi araştırmanın önemli bir kısıtı olarak görülmektedir. Bu sebeple söz konusu araştırmanın ve benzer araştırmaların farklı sektörlerin dâhil edilerek yapılması durumunda elde edilen sonuçların farklılaşabileceği göz önünde bulundurulmalıdır. Araştırmanın boylamsal olmaması diğer önemli kısıtlardan biri olarak görülmektedir. Bu sebeple bu kısitın ortadan kaldırılması ya da etkisinin asgari düzeylere indirilmesi bağlamında belirli aralıklarla elde edilecek araştırma sonuçlarının daha açıklayıcı olabileceği tarafımızca değerlendirilmektedir. Akademisyenlere, bu çalışma doğrultusunda yapılacak gelecek araştırmalarda, Türkiye'de farklı sektörlerdeki, farklı ölçekte ve farklı örgüt kültürleri olan işletmelerden sağlanan verilerin analizi suretiyle, elde edilecek verilerle söz konusu araştırma değişkenlerine yönelik etkilerin araştırılması ve konuyla ilgili daha geniş bir perspektif sağlanması hususu önerilebilir.

Son Not: Bu çalışma, 3-4 Kasım 2017 tarihlerinde Antalya' da düzenlenmiş olan "5. Örgütsel Davranış Kongresi'nde sunulmuş genişletilmiş özetin revize edilmiş halidir. 


\section{KAYNAKÇA}

Ackfeldt, A.L., Coote, L. V., (2005). "A study of organizational citizenship behaviors in a retail setting", Journal of Business Research, Vol. 58, 151-159.

Akkoç, İ., Turunç, Ö., Çalışkan, A., (2011). "Gelişim kültürü ve lider desteğinin yenilikçi davranış ve iş performansına etkisi: İş-aile çatışmasının aracılık rolü”, "İş, Güç" Endüstri İlişkileri ve İnsan Kaynakları Dergisi, Cilt. 13, Sayı: 4, 83-114.

Aksoy, B., (2005). "Bilgi teknolojilerinin yarattı̆̆ı örgütsel değişim: Nasıl bir insan kaynakları yönetimi?”, Bilgi Dünyası, Cilt. 6, Say1: 1, 58-77.

Akyıldız, H., Turunç, Ö., (2013). Çalışma Psikolojisi, Alter Yayıncılık, Ankara.

Arıkan, Ö. U., (2017). "Sağlık sektörü çalışanlarında; dönüşümcü liderliğin yenilikçi davranış üzerine etkisi ve örgütsel vatandaşlık davranışları'nın bu etkideki aracılık rolü üzerine bir araştırma: Mersin ili örneği’, Yüksek Lisans Tezi, Toros Üniversitesi, Mersin.

Babin, B. J., Boles, J. S., (1996). "The effects perceived coworker involvement and supervisor support on service provider role stress, performance and job satisfaction", Journal of Retailing, Vol. 72, No. 1, 57-75.

Baron, R. M., Kenny, D. A., (1986), “The moderator mediator variable distinction in social psychological research: conceptual, strategic, and statistical considerations", Journal of Personality and Social Psychology, No. 51, 11731182 .

Bhanthumnavin, D., (2003). "Perceived social support fromsupervisor and group mambers psychological and situational characteristics as predictors of subordinate performance in work units", Human Resource Development Quarterly, No. 14, 74-97.

Börekçi, Y. D., (2007). "Influence of information and communication technologies (1ct) on leader-follower relations, leader behavior and follower's positive work attitudes", Doctoral Dissertation, Boğaziçi Üniversitesi, İstanbul.

Bükeç, C. M., (2007). "Örgütlerde bilgi yönetiminde kullanılan bilgi ve iletişim teknolojilerinin örgüt kültürüne etkisi”, Yüksek Lisans Tezi, Dumlupınar Üniversitesi SBE, Kütahya.

Cummings, L. L., O’Connell, M.J., (1978). “Organizational innovation”, Journal of Business Research, No. 6, 33-50.

Çalışkan, A., Akkoç, İ., Turunç, Ö., (2011), "Örgütsel performansın arttırılmasında motivasyonel davranışların rolü: Yenilikçilik ve girişimciliğin aracılık rolü”, Süleyman Demirel Üniversitesi İktisadi ve İdari Bilimler Fakültesi Dergisi, Cilt. 16, Say1: 3, 363-401.

Demirhan, S., (2012). "Fen ve teknoloji öğretmenlerinin bilgi ve iletişim teknolojilerine ilişkin özyeterlik algıları ve bilgi iletişim teknolojilerini kullanım durumları (Denizli ili örneği)", Yüksek Lisans Tezi, Pamukkale Üniversitesi FBE, Pamukkale. 
Dong, L., (2006). "Modelling leadership influence on information systems 1mplementation effectiveness", International Journal of Information Systems and Change Management, Vol. 1, No. 4, 439-452.

Elenkov, D. S., Manev I. M., (2009). "Senior expatriate leadership's effects on innovation and the role of cultural intelligence", Journal of World Business, No. 44, 357-369.

Farris, G. F., (1973). "The technical supervisor: Beyond the Peter principle”, Technical Review, No. 75, 25-39.

Feeny D.F., Willcocks L.P., (1998). "Core IS capabilities for exploiting information technology”, Sloan Management Review, Vol. 39, No. 3, 9-22.

Fındıklı Afacan, M., (2014). “Algılanan lider desteği ve algılanan örgütsel destek ile işten ayrılma niyeti ilişkisinde örgütsel özdeşleşmenin aracılık rolü: İstanbul'da kamu çalışanları üzerine bir araştırma”, İstanbul Üniversitesi İşletme Fakültesi İşletme İktisadı Enstitüsü Yönetim Dergisi, Cilt. 25, Sayı: 77, 136-157.

Gökoğlu, S., Çakıroğlu, Ü., (2014). "Bir teknoloji lideri olarak bilişim teknolojileri öğretmeni”, II. International Instructional Technologies \& Teacher Education Symposium Proceedings, 20-22 May1s 2014, Afyonkarahisar.

Hasenfeld, Y., (1983). Human service organizations, Upper Saddle River, N.J.: Prentice Hall.

Howell, J. M., Avolio, B. J., (1993). "Transformational leadership, transactional leadership, locus of control, and support for innovations: Key predictors of consolidated-business-unit performance", Journal of Applied Psychology, Vol. 78, No. 6, 891-903.

Işıkl1, M., (2010). "Sınıf öğretmenlerinin bilgi ve iletişim teknolojilerini kullanım düzeylerinin yeniliğin yayılımı kuramına göre incelenmesi”, Yüksek Lisans Tezi, Uşak Üniversitesi, Uşak.

Jung, D. L, Chow, C., Wu, C., (2003). "The role of transformational leadership in enhancing organizational innovation: Hypotheses and some preliminary findings", Leadership Quarterly, No. 14, 523-544.

Kisfalvi, V., Pitcher, P., (2003). "Doing what feels right: The influence of ceo character and emotions on top management team dynamics", Journal of Management Inquiry, No. 12, 42-66.

Kohli, R., Melville, N. P., (2009). "Learning to build an IT innovation platform", Communications of the ACM, Vol. 52, No. 8, 122-126.

Kossek, E. E., Pichler, S., Bodner, T., Hammer, L. B., (2011). "Workplace social support and work-family conflict: A meta-analysis clarifying the influence of general and work-family specific supervisor and organizational support", Personel Psychology, Vol. 64, No. 2, 289-313.

Köksal, A., (1981). Bilişim terimleri sözlüğ̈̈, Türk Dil Kurumu Yayınları: Ankara.

Li, X., Zheng, Y., (2014). "The influential factors of employees' innovative behavior and the management advices", Journal of Service Science and Management, No. 7, 446-450. 
Melville, N. P., (2010). "Information systems innovation for environmental sustainability”, MIS Quarterly, Vol. 34, No. 1, 1-21.

Mone., M. A., Mckinley, W., Barker, V. L., (1998). "Organizational decline and 1nnovation: a contingency framework", Academy of Management Review, Vol. 23, No. 1, 115-132.

Moorhead, G., Griffin R. W., (2001). Organizational behavior managing people and organizations, Sixth Edition, Hougton Mifflin Company, Boston New York.

Mustafa, H. H., (2016). "Bilgi ve iletişim teknolojileri ve örgütsel yenilik: Niteliksel bir analiz”, Doktora Tezi, Yaşar Üniversitesi, İzmir.

Netemeyer, R. G, Boles J. S, Mckee D. O., Mcmurrian, R. (1997). “An investigation into the antecedents of organizational citizenship behaviors in a personal selling context", Journal of Marketing, No. 613, 85-98.

Oldham, G. R., Cummings, A., (1996). "Employee creativity: personal and contextual factors at work", Academy of Management Journal, Vol 39, No. 3, 607-634.

Osborne, S. P., (1998). "Naming the beast: Defining and classifying service innovations in social policy", Human Relations, No. 51, 1133-1155.

Osterloh, M., Frey, B., (2000). "Motivation, knowledge transfer, and organizational forms", Organization Science, No. 11, 538-550.

Öz, E. Ü., (2007). Duygusal emek davranışlarının çalışanların iş sonuçlarına etkisi. Beta Yayıncıl1k: İstanbul.

Podsakoff, P. M., Mackenzie S. B., Bommer W. H., (1996). "Transformational leader behaviors and substitutes for leadership as determinants of employee satisfaction, commitment, trust, and organizational citizenship behaviors", Journal of Management, No. 222, 259-298.

Rhoades, L., Eisenberger, R., (2002). "Perceived organizational support: A review of the literature", Journal of Applied Psychology, No. 87, 698-714.

Samuel, C. C., (2000). Modern management diversity, quality, ethics \& the global environment, Prentice Hall International Inc., London.

Sastry, M. A., (1999). "Managing Strategic Innovation and change”, Administrative Science Quarterly, Vol. 44, No. 2, 420-422.

Schin, J., McClomb, G. E., (1998). "Top executive leadership and organizational 1nnovation: an Investigation of nonprofit human service organizations", SocialWork Administration, Vol. 22, No. 3, 1-21.

Scott, S., Bruce, R., (1994). "The influence of leadership, individual attributes, and climate on innovative behavior: A model of individual innovation in the workplace", Academy Of Management Journal, No. 37, 580-607.

Sekaran, U., (1992). Research methods for business, John Wiley ve Sons, Inc.: Canada.

Som, A., (2008). "Innovative human resource management and corporate performance in the context of economic liberalization in India", The International Journal of Human Resource Management, Vol. 19, No. 7, 1278-1297. 
Stinglhamber, F., Vandenberghe C., (2003). "Organizations and supervisors as sources of support and targets of commitment: A longitudinal study", Journal of Organizational Behavior, No. 24, 251-270.

Thompson, V. A., (1965). "Bureaucracy and innovation", Administrative Science Quarterly, No. 5, 1-20.

Turgut, E., Beğenirbaş, M., (2013). "Çalışanların yenilikçi davranışları üzerinde sosyal sermaye ve yenilikçi iklimin rolü: Sağlık sektöründe bir araştırma”, KHO Bilim Dergisi, Cilt. 23, Sayı: 2, 101-124.

Türen, U., Gökmen, Y., Tokmak, İ., (2013). “İnsan kaynakları yönetimi uygulamalarının işletme performansına etkisi: İşletmelerin sahip oldukları bilgi ve iletişim teknolojileri kabiliyetlerinin aracılık rolü”, Business and Economics Research Journal, Cilt. 4, Sayı: 4, 103-129.

Van de Ven, A. H., (1986). "Central problem in the management of innovation", Management Science, No. 32, 509-607.

West, M. A., Farr, J. L., (1989). "Innovation at work: Psychological perspectives", Social Behavior, No. 4, 15-30.

West, M. A., Farr, J. L., (1990). Innovation at work. In M. A. West \& J. L. Farr (ed.), Innovation and Creativity at Work (s. 3- 13). Chichester: John Wileys.

West, M. A., Borrill, C., Dawson, J., Brodbeck, F., Shapiro, D., Haward, B., (2003). "Leadership clarity and team innovation in health care", Leadership Quarterly, No. 14, 393-410.

Woodman, R. W., Sawyer, J. E., Griffin, R. W., (1993). "Toward a theory of organizational creativity", Academy of Management Review, Cilt. 18, No. 2, 293321.

Yılmaz Börekçi, D., (2009). "Leader's ICT usage's influence on follower's positive work attitudes via perceived leader-follower relations", Journal of Leadership \& Organizational Studies, Cilt. 16, No. 2, 141-158.

Yuan, F., Woodman, R. W., (2010). "Innovatıve behavior in the workplace: The role of performance and image outcome expectations", Academy of Management Journal, Cilt. 53, No. 2, 323-342. 


\section{Influence Of Organization's Knowledge And Communication Skills On Employee's Innovation Behavior: Mediating Role Of Leader Support}

\author{
Nazmiye Ülkü PEKKAN \\ Osmaniye Korkut Ata \\ University \\ Osmaniye, Turkey \\ orcid.org/0000-0001-7298-0552 \\ nazmiyeulku.pekkan@gmail.com
}

\author{
Abdullah ÇALIŞKAN \\ Toros University \\ Vocational School of Health Sciences \\ Mersin, Turkey \\ orcid.org/0000-0001-5746-8550 \\ abdullah.caliskan@toros.edu.tr
}

\section{Extensive Summary}

\section{Introduction}

Given today's competitive conditions, organizations must develop a variety of methods and strategies to survive under these challenging conditions and to make a difference by getting out of their competitors (Som, 2008). These changes and developments take place especially in the field of information and communication technology. In the past, there were many systems used only as information technology tools. Over time, this situation has changed.

Today, there are many information and communication technologies that are based on similar sub-structures and that enable transfer among each other. The most striking example of this situation, the internet has emerged as an information technology tool and is now being used as a means of communication tool (Vijayanand ve Ananda, 2003 akt. Börekçi, 2007). This rapid development in information and communication technologies is also reflected in business processes.

Organizations have to develop skills to translate these developments into business processes and to use them effectively. Being able to adapt to the innovations in the field will have positive effects on the performance of the organizations. One of the most important factors for businesses is the adaptation of human resources to innovations and the promotion of their creativity.

In this context; the main problem field of study is to identify the impact of information and communication technologies capabilities of the organizations operating in the electronic communication sector on the innovative behaviors of employees and to determine the mediating role of leader support on this impact.

\section{Method}

In this study, employees of organizations operating in electronic communication sector in Ankara were dealt. There are approximately 15.000 people working at this universe.

The aim of this study is to investigate the impact of four sub-dimensions of information and communication technologies capabilities (the information technology education, information technology strategy, communication and current follow-up applications, business intelligence applications) on the innovative behaviors of 
employees and to determine the mediating role of leader support on this impact. It was tried to determine the relations between the variables with the data gathered from 568 employees by using the questionnaire prepared in this study.

To measure of organizations information and communication technologies capabilities the Information and Communication Technologies Capabilities Scale (TSIS) was used developed by Feeny and Willcocks (1998) and made validity in Turkish by Türen and friends (2013). The scale consist of 23 items and 4 dimensions which are the information technology education (5 items), information technology strategy (6 items), communication and current follow-up applications (6 items), business intelligence applications (6 items).

Leader Support Scale, which was developed by Netemeyer and friends (1997) and made validity in Turkish by Akkoç and friends (2011) was used to measure the perception of employees leader support. The scale consist of 5 items and 1 dimension.

Innovative Behaviors Scale, which was developed by Scott and Bruce (1994) and made validity in Turkish by Çalışkan and friends (2011) was used to measure of employees innovative behaviors. The scale consist of 6 items and 1 dimension.

Analyzes were made on the model generated in the data obtained from the sample. In this context, firstly, confirmatory factor analysis of each variable was performed and then correlations between variables were determined. Hypotheses and mediated effects were tested by hierarchical regression analysis and then, sobel tests were conducted to test mediator effects.

The demographic characteristics of the participants are examined via frequency analysis. The findings suggest that; $57 \%$ of 568 participants were male and $69,7 \%$ were married. $34.3 \%$ of the participants constitute the biggest share with 33-40 age group. $64.7 \%$ of the participants are educated at bachelors level.

\section{Conclusion and Discussion}

In this study, the effect of four sub-dimensions of information and communication technologies capabilities (the information technology education, information technology strategy, communication and current follow-up applications, business intelligence applications) on the innovative behaviors of employees and to determine the mediating role of leader support on this impact was investigated.

The effects of the information and communication technologies capabilities variable included in this study on the innovative behaviors of employees were tried to be predicted with the help of correlation and regression analysis. As a result of the correlation analysis made to determine the relations between the variables; it has been determined that four dimensions of information and communication technologies capabilities (the information technology education, information technology strategy, communication and current follow-up applications, business intelligence applications) have positive and significant relationships between innovative behaviors of employees.

When another result of this study is examined, it is determined that leader support is related to innovative behaviors of employees and increased innovative behaviors of employees as a whole significantly and positively.

The ability of information and communication technologies; it is important that employees develop innovative behavior patterns and apply new ideas and suggestions 
effectively for organizational purposes. Moreover, the ability of information and communication technologies should be seen as an important achievement in getting rid of other organizations under intense competition conditions. In this context, the high ability of an organization to effectively use information and communication technologies it has will increase the innovative behavior of employees in the organization. As a matter of fact, these results confirm these expectations.

It is thought that the ability of information and communication technologies is influential on employees' innovative behavior and that this effect can be influenced by some variables and thus reflected in output variables. From this point of view, the mediating role of leadership support in the impact of information and communication technology capabilities sub-dimensions on employees' innovative behaviors is explored. As a result of this analysis, it has been determined that the support of the four subdimensions of information and communication technology capabilities (the information technology education, information technology strategy, communication and current follow-up applications, business intelligence applications) is partially mediated by innovative behavior.

This study is the first study to examine the relationship between information and communication technologies capabilities and innovative behaviors. Therefore, it has an original value in terms of contribution to the scientific accumulation and business life.

In subsequent researches to be conducted in parallel with this study, it may be suggested to researchers that the results of the researches that will be obtained at certain intervals may be more descriptive. In addition, more comprehensive results can be obtained if the research is done with different sampling methods and at different organizational cultures. 